\title{
Irrationality of managers' behavior in corporate financial decision making
} Marcin Banaszek

Dr, Katedra Ekonomii i Finansów, Wydział Prawa i Nauk Społecznych, Uniwersytet Jana Kochanowskiego w Kielcach, Poland.

Email: marcin.banaszek@ujk.edu.pl

\section{Keywords}

Behavioral Finance, Enterprise, Economic Psychology, Decision Rationality.

\section{Article History}

Received on $5^{\text {th }}$ September 2021

Accepted on $9^{\text {th }}$ October 2021

Published on $18^{\text {th }}$ October 2021

Cite this article

Banaszek, M. (2021). Irrationality of managers' behavior in corporate financial decision making. Humanities \& Social

Sciences Reviews, 9(5), 51-56.

https://doi.org/10.18510/hssr.2021.958

Copyright @ Author

Publishing License

This work is licensed under a Creative Commons Attribution-Share Alike 4.0 International License

\begin{abstract}
Purpose of the study: The subject of consideration is the behavioral aspects of corporate finance. The consideration is devoted to the basic inclinations of psychological nature characteristic of managers. The main purpose of the article is to characterize the irrational behavior of managers in the process of financial decision-making in the enterprise.
\end{abstract}

Methodology: The paper was prepared with the use the critical literature review method mainly in the field of behavioral corporate finance.

Main findings: The discussion shows that behavioral corporate finance focuses mainly on cognitive and motivational-emotional processes in managers, which may occur in various decision areas within which managers make choices. There are three groups of psychological phenomena and inclinations that are characteristic of managers who manage business entities, namely predispositions to systematic inference errors, heuristics, and the presentation effect.

Application of the study: The presented article refers to the irrational behavior of managers in the process of making financial decisions in the company. It implies reflections in such scientific fields as, among others, economics and finance, management and psychology. The use of the tools of psychology allows analyzing the problems of financial decision-making of managers in the enterprise, noticing in them some deviations from rationality that can affect the efficiency of the enterprise. The content of the article can be useful for managers making financial decisions in an enterprise.

Originality/Novelty of the study: Behavioral finance is a young discipline of finance, the scientific output of which in Poland is still small. Behavioral aspects are just beginning to gain importance in the decisionmaking process, especially the financial one. The tendencies of managers to irrationality in the decision-making process presented in this article allow us to better understand the errors, psychological factors that may cause wrong decisions, which in turn may translate into poorer financial condition of the whole enterprise. The article can inspire further research and inquiry in the field of behavioral finance and contribute to other interesting scientific studies. 


\section{NIERACJONALNOŚĆ ZACHOWAŃ MENEDŻERÓW W PROCESIE PODEJMOWANIA DECYZJI FINANSOWYCH W PRZEDSIĘBIORSTWIE \\ Marcin Banaszek \\ Dr, Katedra Ekonomii i Finansów, Wydział Prawa i Nauk Społecznych, Uniwersytet Jana Kochanowskiego w Kielcach, Poland. \\ E-mail: marcin.banaszek@ujk.edu.pl}

\author{
Slowa kluczowe \\ finanse behawioralne, przedsiębiorstwo, psychologia \\ ekonomiczna, racjonalność decyzji.
}

Historia artykulu

Otrzymano 5 września 2021

Przyjęta 9 październik 2021

Opublikowane 18 październik 2021

\section{Cite this article}

Banaszek, M. (2021). Irrationality of managers'

behavior in corporate financial decision making.

Humanities \& Social Sciences Reviews, 9(5), 51-56.

https://doi.org/10.18510/hssr.2021.958

Copyright @Author

Publishing License

This work is licensed under a Creative Commons Attribution-Share Alike 4.0 International License

\section{Streszczenie}

Cel badawczy: Przedmiotem rozważań są aspekty behawioralnych finansów przedsiębiorstw. Rozważania poświęcono podstawowym skłonnościom o charakterze psychologicznym charakterystycznym dla menedżerów. Głównym celem artykułu jest charakterystyka nieracjonalnych zachowań menedżerów w procesie podejmowania decyzji finansowych w przedsiębiorstwie.

Metodologia: Artykuł przygotowano z wykorzystaniem metody krytycznego przeglądu literatury głównie z zakresu behawioralnych finansów przedsiębiorstw.

Glówne wnioski: Z rozważań wynika, że behawioralne finanse przedsiębiorstw skupiają się głównie na procesach poznawczych i motywacyjno-emocjonalnych u menedżerów, które moga zachodzić na różnych obszarach decyzyjnych, w obrębie których zarządzający dokonują wyborów. Wyróżnia się trzy grupy zjawisk i inklinacji o charakterze psychologicznym, które są charakterystyczne dla menedżerów zarządzających podmiotami gospodarczymi, a mianowicie predyspozycje do systematycznych błędów wnioskowania, heurystyki oraz efekt prezentacji.

Zastosowanie badania: Prezentowany artykuł odnosi się do irracjonalnych zachowań menedżerów w procesie podejmowania decyzji finansowych $\mathrm{w}$ przedsiębiorstwie. Implikuje to przemyślenia w takich dziedzinach naukowych jak, m.in. ekonomia i finanse, zarządzanie i psychologia. Wykorzystanie narzędzi psychologii pozwala analizować problemy podejmowania decyzji finansowych menedżerów $\mathrm{w}$ przedsiębiorstwie, zauważając $\mathrm{u}$ nich pewne odstępstwa od racjonalności mogące mieć wpływ na efektywność przedsiębiorstwa. Treść zawarta $\mathrm{w}$ artykule może być przydatna dla menedżerów podejmujących decyzje finansowe w przedsiębiorstwie.

Oryginalność badań: Finanse behawioralne to młoda dyscyplina finansów, której dorobek naukowy w Polsce nadal jest niewielki. Aspekty behawioralne dopiero zaczynają nabierać znaczenia w procesie podejmowania decyzji, szczególnie finansowych. Przedstawione w niniejszym artykule skłonności menedżerów do nieracjonalności w procesie podejmowania decyzji pozwalają lepiej zrozumieć błędy, czynniki psychologiczne, które mogą spowodować podjęcie niewłaściwych decyzji, co z kolei może przełożyć się na słabszą kondycję finansową całego przedsiębiorstwa. Artykuł może inspirować do dalszych badań i dociekań w sferze finansów behawioralnych oraz przyczynić się do powstawania innych ciekawych opracowań naukowych.

\section{Wprowadzenie}

Współcześnie wśród naukowców i przedsiębiorców można dostrzec coraz większe zainteresowanie wiedzą z zakresu finansów behawioralnych. Ten obszar badawczy wiążący ze sobą wiedzę przede wszystkim z zakresu finansów i psychologii stanowi obecnie wyzwanie dla dominującej dotychczas neoklasycznej teorii finansów.

Behawioralne finanse przedsiębiorstw, to część subdyscypliny finansów przedsiębiorstw. Przedstawiciele nurtu behawiorystycznego przyjmują, że ludzie nie są w stanie posługiwać się ścisłymi zasadami racjonalności, a raczej korzystają z różnego rodzaju heurystyk, czyli skrótowych i niekiedy zawodnych sposobów przetwarzania informacji, które niekoniecznie prowadzą do maksymalizacji bogactwa (Zielonka, 2021, s. 10).

W ramach behawioralnego podejścia do finansów przedsiębiorstw zakłada się, że skłonności i implikacje psychologiczne wywierają wpływ na procesy przebiegające na rynkach finansowych oraz decyzje, które podejmowane 
są w przedsiębiorstwie. Należy podkreślić, iż psychologiczne uwarunkowania jak i skłonności uczestników rynku wywierają istotny wpływ na przebiegające na nim procesy. W konsekwencji w ramach behawioralnych finansów przedsiębiorstw powstało wiele koncepcji, których celem jest wyjaśnienie szeregu problemów z zakresu zarządzania finansami (Gajdka, 2013, s. 12).

Behawioralne finanse przedsiębiorstw skupiają się głównie na procesach poznawczych i motywacyjno-emocjonalnych u menedżerów, które mogą zachodzić na różnych obszarach decyzyjnych, w obrębie których zarządzający dokonują wyborów. Wskazują pewne skłonności, błędy, które zakorzenione są w ludzkiej psychice.

\section{Decyzje finansowe w przedsiębiorstwie}

Proces podejmowania decyzji w przedsiębiorstwie, to obecnie najważniejszy element w zarządzaniu firmą. Często decyzja stanowi o być albo nie być przedsiębiorstwa na rynku. Dlatego wymaga się od menedżerów, aby wciąż się rozwijali, dokształcali w sprawnym sposobie podejmowania decyzji. Przy podejmowaniu decyzji nie można kierować się tylko intuicją czy doświadczeniami, ale należy wykorzystywać możliwości drzemiące w różnych technikach, narzędziach i systemach wspomagających podjęcie właściwych decyzji w przedsiębiorstwie (Wójcik, 2009, s. 5-14).

Tradycyjny zakres materiału nauczany w ramach zarządzania finansami przedsiębiorstwa dostarcza bogatych technik, które $\mathrm{w}$ teorii powinny pomóc menedżerom w podejmowaniu właściwych decyzji maksymalizujących wartość przedsiębiorstwa. Jednak w praktyce osoby zarządzające napotykają na różnego rodzaju mankamenty, w tym również te wywołane czynnikami psychologicznymi, które dość często powstrzymują menedżerów od skutecznego wykorzystania tych technik. Finanse behawioralne są właśnie tą subdyscypliną, która ma za zadanie uzmysłowić na czym polegają owe czynniki psychologiczne i pomóc menedżerom w podejmowaniu najlepszych decyzji (Gajdka, 2013, s. 35-36).

Decyzje finansowe należy definiować jako wolny wybór jednego z przygotowanych wariantów działania w zakresie zjawiska i procesów pieniężnych (Nogalski Falencikowski, 2005, s. 27-31). W przypadku gdy decyzjom finansowym towarzyszy przepływ pieniężny działalność przedsiębiorstw jest skupiona na trzech obszarach (Kordela i Pawłowski, 2018, s. 9):

- operacyjnym - podejmowanie decyzji dotyczących podstawowej działalności przedsiębiorstwa;

- inwestycyjnym - podejmowanie decyzji dotyczących zakupu lub sprzedaży rzeczowych aktywów trwałych, wartości niematerialnych i prawnych oraz inwestycji finansowych;

- finansowym - podejmowanie decyzji dotyczących kształtowania wielkości i struktury kapitału wykorzystywanego przez przedsiębiorstwo.

Warto zaznaczyć, że w wyniku działania w obszarze operacyjnym i inwestycyjnym przedsiębiorstwo wypracowuje wewnętrzne źródła finansowania, do których można zaliczyć: zysk zatrzymany, wpływy ze zbycia aktywów lub z ich transformacji (Kordela i Pawłowski, 2018, s. 9).

Należy również pamiętać, że decyzja powinna spełniać swoje założenie, czyli powinna efektywnie i skutecznie zapewniać przedsiębiorstwu stabilną pozycję na rynku. Dodatkowo decyzja powinna mieć swój określony czas, w którym występuje, tak aby zsynchronizował się on z innymi czynnikami, które zachodzą w otoczeniu. W ten sposób będzie można sprawnie zapewnić optymalny efekt ekonomiczny (Motylska-Kuźma i Wieprow, 2017, s. 130).

Można wyróżnić dwa podstawowe modele podejmowania decyzji: klasyczny i menedżerski lub inaczej administracyjny. Model klasyczny zakłada racjonalną i logiczną naturę osób decyzyjnych oraz przyjmuje, że podjęte przez nich decyzje najlepiej służą interesom przedsiębiorstwa. Do zadań menedżera w tym modelu należy pozyskiwanie pełnej informacji, wyeliminowanie niepewności oraz ocenianie wszystkiego racjonalnie i logicznie. Z kolei model menedżerski uwzględnia aspekty behawioralne, czyli czynniki, które mogą powodować nieracjonalność decyzji. Model ten zakłada, że menedżerowie podejmując decyzje mają ograniczoną racjonalność, niepełną informację, niekompletną wiedzę czy umiejętności. Osoby te są skłonne zadowalać się pierwszym wystarczalnym rozwiązaniem (Motylska-Kuźma i Wieprow, 2017, s. 131).

\section{Skłonności menedżerów do nieracjonalności w podejmowaniu decyzji finansowych}

$\mathrm{Na}$ wstępie warto podkreślić, że skłonności o charakterze psychologicznym, które mogą prowadzić do działań sprzecznych z zasadą racjonalności w rozumieniu neoklasycznej teorii finansów, dotyczą w zasadzie całej populacji, nie tylko menedżerów. Podczas analizy zachowań osób działających na rynku kapitałowym można wyróżnić takie skłonności o charakterze psychologicznym jak: nadmierna pewność własnej wiedzy i umiejętności, heurystyka dostępności, heurystyka zakotwiczenia, heurystyka reprezentatywności, konserwatyzm oraz dodatni efekt świeżości, polegający na prognozowaniu odwrócenia trendu (Gajdka, 2013, s. 35).

Według H. Shefrina można wyróżnić trzy grupy zjawisk i inklinacji o charakterze psychologicznym, które są charakterystyczne dla menedżerów zarządzających podmiotami gospodarczymi, a mianowicie predyspozycje do systematycznych błędów wnioskowania, heurystyki oraz efekt prezentacji (Gajdka, 2013, s. 36).

Predyspozycje do systematycznych błędów wnioskowania to przede wszystkim nadmierny optymizm (excessive optimism), nadmierna pewność siebie (overconfidence), selektywna percepcja i błąd afirmacji (confirmation bias) oraz błąd kontroli (illusion control). 
Z kolei do heurystyki zalicza się reprezentatywność, dostępność, zakotwiczenie i dostosowanie oraz heurystykę afektu. Mówiąc o efektach prezentacji należy rozumieć efekty wynikające z opisu zadania (Shefrin, 2007, s. 3).

Nadmierny optymizm polega na nierealistycznym przekonaniu menedżerów o pozytywnym przebiegu zdarzeń, które ich dotyczą. Skłonność ta jest odpowiedzialna za wiele niepożądanych działań u menedżerów, jak choćby skłonność do podejmowania nadmiernie ryzykownych zachowań na skutek wiary w zmniejszoną podatność na ich negatywne skutki np. spekulacyjny zakup instrumentów finansowych o dużej zmienności stóp zwrotu (Zielonka, 2021, s. 50-51). Nadmierny optymizm może powodować zarówno zawyżanie prawdopodobieństwa wystąpienia pożądanych wydarzeń rzadkich, jaki i zaniżanie wydarzeń niepożądanych.

Aby ograniczyć niepożądane skutki nadmiernego optymizmu należy dokładnie szacować prawdopodobieństwo odniesienia sukcesu $\mathrm{w}$ podejmowanym działaniu. Warto również zwrócić uwagę na różnice pomiędzy prawdopodobieństwem osiągnięcia sukcesu/porażki a wartością oczekiwaną (Zielonka, 2021, s. 51). Może się wówczas okazać, że mimo wysokiego prawdopodobieństwa sukcesu na skutek (mało prawdopodobnej) porażki wypłata będzie silnie ujemna. Menedżerowie skupiają swoją uwagę na wysokim prawdopodobieństwie sukcesu i nie dostrzegają dramatycznie niskiej wypłaty (Taleb, 2004, s. 56).

Kolejną skłonnością o charakterze psychologicznym charakterystyczną dla menedżerów jest nadmierna pewność siebie, czyli przesadna wiara we własne możliwości. Jednostki z nadmierną pewnością siebie często wykazują tendencję do przeszacowywania możliwości sporządzania właściwych prognoz. Nadmierna ufność we własne siły powoduje również błędną ocenę możliwości oraz ograniczenia własnej wiedzy. Przekonanie menedżerów o własnych możliwościach, zdolnościach i wiedzy nie jest adekwatne do rzeczywistości (Gajdka, 2013, s. 37-38).

Zdaniem Szyszki ta nadmierna pewność siebie u menedżerów może przejawiać się na cztery zasadnicze sposoby (Szyszka, 2009, s. 48-51):

- w efekcie ponadprzeciętności - wynika z faktu, że jednostki budując przekonania dotyczące rzeczywistości przypisują swoim umiejętnościom, wiedzy i możliwościom ponadprzeciętny poziom;

- efekcie kalibracji - przejawia się w tym, że np. jednostki proszone o podanie prognozy (w określonym przedziale ufności) zaczynają wykazywać tendencję do udzielania odpowiedzi wskazujących na nadmierne przekonanie o precyzji posiadanej wiedzy;

- iluzji kontroli - polega na przekonaniu, że można swymi działaniami pozytywnie wpłynąć na zdarzenia losowe;

- nierealistycznym optymizmie - wyraża się w „myśleniu życzeniowym”, jego przejawem mogą być błędy w planowaniu.

W celu eliminacji nadmiernej pewności własnej wiedzy i umiejętności należy w sposób krytyczny podchodzić do własnych sądów i jeśli to możliwe konsultować się z niezależnymi ekspertami.

Jednym z ważnych czynników, który zniekształca proces wnioskowania jest selektywna percepcja informacji, która polega na tym, że jednostka działając pod presją czasu, wychwytuje jedynie te informacje, które pasują do przewidywanych przez nią scenariuszy wydarzeń (Shefrin, 2007, s. 66). Przyczyn selektywnej percepcji informacji należy upatrywać w ograniczonych możliwościach postrzegania informacji lub w celowym unikaniu informacji, które mogłyby zaburzyć posiadane przez jednostkę przekonania lub poglądy. Jednostka poszukuje dowodów na potwierdzenie własnych sądów, przy jednoczesnym ignorowaniu faktów podważających własne przewidywania - błąd afirmacji (Gajdka, 2013, s. 38-39).

Z kolei błąd kontroli polega na subiektywnym przeświadczeniu jednostki, że odniesie sukces. Przeświadczenie to jest niewspółmiernie wyższe $\mathrm{w}$ porównaniu $\mathrm{z}$ rzeczywistym prawdopodobieństwem. Decyzje, które podejmują menedżerowie zależą od kilku czynników między innymi od ich kompetencji, umiejętności, doświadczenia, ale także od szczęścia. Można jednak zaobserwować, że menedżerowie mają skłonności do przeszacowywania możliwości kontroli nad skutkami decyzji (Gajdka, 2013, s. 39).

Kolejną grupą zjawisk i inklinacji o charakterze psychologicznym są heurystyki. Heurystyka reprezentatywności to formułowanie opinii na temat prawdopodobieństwa występowania zdarzeń na podstawie niewielkiej próby, $\mathrm{z}$ pominięciem procedur statystycznych. Tego typu heurystyka dość często widoczna jest wśród menedżerów. Wyraża się ona tym, że często wydają oni opinie, dokonując ocen i formułując prognozy w oparciu o analogię lub stereotypy (Zielonka, 2021, s. 67).

Heurystyka reprezentatywności może się również przejawiać jako skłonność do uznawania, że dowolnie mała próba będzie mieć cechy charakterystyczne dla całej populacji - heurystyka ta została nazwana prawem małych liczb lub ignorowaniem wielkości próby, rozumianym jako ułomność poznawcza zniekształcająca prawo wielkich liczb Jakoba Bernoullego (Zielonka, 2021, s. 67-68).

Heurystyka dostępności polega na tym, że jednostka tworzy przekonanie o prawdopodobieństwie lub częstości zdarzeń na podstawie łatwości przywolywania w myślach stosowanych doświadczeń lub konotacji (Cieślak, 2003, s. 50). D. Kahneman i A. Tversky wykazali, że jednostka przypisuje tym wyższe prawdopodobieństwo pojawienia się jakiegoś 
zdarzenia, im więcej podobnych przykładów zna oraz im większa jest ich wyrazistość (Kahneman i Tversky 1973, s. 237).

E. Stepahn wyróżnił dwa podstawowe rodzaje dostępności (Stephan, 1999, s. 101):

- dostępność oparta na doświadczeniu - ludzie mają większe zaufanie do tego co jest im już znane, co wcześniej widzieli lub o czym słyszeli, ale ignorują przy tym fakt, że próba, z którą mieli do czynienia jest niereprezentatywna;

- dostępność związana z pamięcią - ludzie mają większe zaufanie do tego co z łatwością mogą przywołać z pamięci, jakieś wcześniej zapamiętane fakty. Ten rodzaj dostępności związany jest m.in. z poziomem uwagi podczas percepcji, znajomością tematyki, której dotyczą zapamiętywane bodźce oraz bliskością czasową i przestrzenną.

Kolejnym czynnikiem, który zniekształca proces wnioskowania jest zakotwiczenie i dostosowanie. Podczas dokonywania szacowań nieznanych wielkości menedżerowie opierają się na danych dostępnych w danym momencie, nawet przypadkowych wartościach, a następnie odnoszą te wartości do własnych szacowań - zjawisko to nosi nazwę zakotwiczenia (Zielonka, 2021, s. 61). Badania empiryczne potwierdzają, że ludzie estymują wielkości na podstawie początkowo zasugerowanego poziomu tzw. kotwicy, którą dostosowują odpowiednio do celu dokonania ostatecznej oceny (Cieślak, 2003, s. 63). Znajomość początkowych liczb powoduje, że oceny i prognozy menedżerów nie różnią się zbytnio od siebie (Gajdka, 2013, s. 41). Efekt zakotwiczenia występuje, gdy menedżerowie nie są świadomi, że odbierana przez nich wiadomość może stanowić zakotwiczenie. Co ciekawe osoby zarządzające przedsiębiorstwem ulegają zakotwiczeniu nawet wtedy, gdy są przekonani, że docierające do nich dane nie mają żadnego znaczenia (Sunstein, 2004, s. 87).

Heurystyka afektu polega na tym, że menedżerowie podejmują decyzje kierując się tym, co emocjonalnie wydaje im się właściwe. Zachowują się tak jak podpowiada im intuicja (Gajdka, 2013, s. 41). Odczuwany stan emocjonalny (afekt) staje się niejako wskaźnikiem w ocenie zjawisk. Im większe korzyści przypisuje się pewnej aktywności, tym niżej jest oceniane ryzyko związane $\mathrm{z}$ tą działalnością. Ludzie rzadko postrzegają daną kwestię jako pożyteczną i ryzykowną zarazem. Pożyteczność oraz wysokie ryzyko od strony wartościowania stanowią odmienne koncepcje, dlatego heurystyka afektu powoduje, że rozważane kwestie nie mogą być w ocenie badanych pożyteczne i ryzykowne zarazem (Zielonka, 2021, s. 63). Tak jak w przypadku innych rodzajów heurystyki, takie zachowanie menedżerów może prowadzić do podejmowania błędnych decyzji.

\section{Podsumowanie}

Behawioralne finanse przedsiębiorstw stanowią w ostatnim czasie popularny kierunek badań zarówno wśród teoretyków jak i praktyków gospodarczych. Dorobek finansów behawioralnych pozwala zrozumieć zachowania menedżerów, które dotychczas były trudne do zrozumienia na gruncie teorii neoklasycznej. Należy podkreślić, że nieracjonalność w procesach decyzyjnych występuje tak naprawdę we wszystkich obszarach decyzji finansowych w przedsiębiorstwie. Począwszy od decyzji dotyczących zarządzania płynnością czy rentownością, przez decyzje dotyczące źródła finansowania działalności, po decyzje strategiczne dotyczące lokowania środków pieniężnych w aktywa przedsiębiorstwa. W każdym $\mathrm{z}$ tych przypadków błędy poznawcze i heurystyki mogą spowodować podjęcie niewłaściwych decyzji, co z kolei może przełożyć się na słabszą kondycję finansową całego przedsiębiorstwa. Jednak sama świadomość i wiedza o popełnianych błędach przy podejmowaniu decyzji finansowych nie jest wystarczająca do rozwiązania pojawiających się problemów. Należy jeszcze poszukiwać sposobów radzenia sobie ze zidentyfikowanymi błędami i próbować je wyeliminować.

\section{Bibliografia}

1. Cieślak, A. (2003). Behawioralna ekonomia finansowa. Modyfikacja paradygmatów funkcjonujących w nowoczesnej teorii finansów, w: Materiały i Studia, Zeszyt nr 165, ss. 50-63.

2. Gajdka, J., (2013). Behawioralne finanse przedsiębiorstw. Podstawowe podejścia i koncepcje. Łódź: Wydawnictwo Uniwersytetu Łódzkiego.

3. Kahneman, D. i Tversky, A. (1973). On the Psychology of Prediction, w: Psychological Review, Nr 80, ss. 237. https://doi.org/10.1037/h0034747

4. Kordela, D., Pawłowski, M. (2018). Gospodarka finansowa przedsiębiorstwa. Dlugoterminowe decyzje finansowe. Kraków-Legionowo: edu-Libra.

5. Motylska-Kuźma, A. i Wieprow, J. (2017). Psychologiczne aspekty podejmowania decyzji finansowych w przedsiebiorstwie, w: Finanse, Rynki finansowe, Ubezpieczenia, $\mathrm{Nr}$ 1/2017(85), ss. 130-131. https://doi.org/10.18276/frfu.2017.1.85-11

6. Nogalski, B. i Falencikowski, T., (2005). Aspekty epistemologiczne decyzji finansowych, w: Zarzecki, D. (red.), Zarzadzanie finansami. Biznes, bankowość i finanse na rynkach wschodzacych, Szczecin: Wydawnictwo Uniwersytetu Szczecińskiego, ss. 27-31.

7. Shefrin, H. (2007). Behavioral Corporate Finance. Decision that Create Value, Boston: McGraw Hill / Irwin.

8. Stephan, E. (1999). Die Rolle von Urteilsheuristiken bei Finanzentscheidungen, w: Fisher L., Kutsch T., Stephan E. (red.), Finanzpsychologie, Munchen, Wien: R. Oldenbourg Verlag, ss. 101. https://doi.org/10.1515/9783486801149-005

9. Sunstein, C.R. (2004). Hazardous Heuristics, Chicago: The Law School, The University of Chicago. https://doi.org/10.2307/1600596 
10. Szyszka, A. (2009). Finanse behawioralne. Nowe podejście do inwestowania na rynku kapitałowym. Poznań: Wydawnictwo Uniwersytetu Ekonomicznego w Poznaniu.

11. Taleb, N.N. (2004). Fooled by Randomness. New York: Thomson Texetere.

12. Wójcik M. (2009). Proces podejmowania decyzji w przedsiębiorstwie, www.e-bookowo.pl [dostęp 17.09.2021].

13. Zielonka, P. (2021). Giełda $i$ psychologia. Behawioralne aspekty inwestowania na rynku papierów wartościowych. Warszawa: CeDeWu. 